\title{
Anthropometric values in an elderly French population
}

\author{
BY JACQUES DELARUE ${ }^{1}$, THIERRY CONSTANS ${ }^{2}$, DENIS MALVY3, \\ ALAIN PRADIGNAC ${ }^{4}$, CHARLES COUET ${ }^{1}$ AND FERNAND LAMISSE ${ }^{1 *}$ \\ ${ }^{1}$ Clinique Médicale A et Laboratoire de Nutrition, ${ }^{2}$ Hopital de l'Ermitage et Club Francophone \\ Gériatrie et Nutrition, "Service d'Informaton Médicale et d'Hygiène 37044 - Tours Cedex, France \\ ${ }^{4}$ Service de Nutrition-Endocrinologie-Médecine Interne, Hôpital Hautepierre 67200 - Strasbourg, \\ France
}

(Received 23 July 1992 - Revised 26 February 1993-Accepted I8 March 1993)

\begin{abstract}
We compared anthropometric indices in samples of elderly people aged 65 years and over living in two French areas. The samples were divided into four age-groups $(65-69,70-74,75-79$ and over 80 years). We observed interregional differences in women aged 65-69 years and in men aged 65-74 years. Weight and anthropometric variables related to body fat percentage and to muscle mass showed a decline with age as already reported by others. We established anthropometric percentile values according to sex in pooled subjects when no integrated difference was found. The 50th percentile of arm circumference, muscle arm circumference and triceps skinfold was higher, and the 50th percentile of body mass index was lower than the one reported for the same indices from an elderly Welsh population. Our results show that an interregional difference in anthropometric indices exists in the elderly. The differences which are observed between our results and those reported from a British population emphasize the importance of establishing local values for the elderly population.
\end{abstract}

Anthropometry: Elderly: Nutrition

The alteration of nutritional status is a major health problem in the elderly. Malnutrition is associated with reduced physical activity and increased risk of mortality and morbidity in old people (Lehmann, 1989). Anthropometry provides non-invasive, easy and cheap information on nutritional status. For this reason, it is particularly appropriate for the evaluation of nutritional status in the elderly. If nutritional status were to be monitored in an intervention trial it would be essential to assess changes in relation to baseline measurements. Reference standards would be of value in assessing the baseline in relation to other measures of nutritional status. The evaluation of the nutritional status of elderly subjects by using anthropometry requires anthropometric reference or usual values for comparison. Such values in the elderly are scarce and only a few national anthropometric reference percentiles for the elderly population have been published (Frisancho, 1981; Burr \& Phillips, 1984). Moreover, the need for rationally specific anthropometric reference data has been emphasized previously (Frisancho, 1981; Constans et al. 1990). The aims of our study were: (1) to collect and to compare anthropometric indices in healthy elderly subjects living in two different French towns, (2) to establish typical anthropometric values in a healthy elderly French population.

\section{SUBJECTS AND METHODS}

The study was conducted between February and December 1990, on 626 noninstitutionalized, elderly French subjects, of both sexes, aged more than 65 years and living

$$
\text { * For reprints. }
$$


in two small French towns: Loches (Central France) and Haguenau (East France). Loches and Haguenau were chosen because of known differences in the way of life. Names and addresses of the subjects were obtained from the registers of births, marriages and deaths. In Loches (7100 residents) all 1246 registered subjects over 65 years were sent a letter explaining the purpose of the study: $266(21 \%)$ subjects agreed to participate (145 women and $121 \mathrm{men}$ ). In Haguenau (29 100 residents) we randomized 1500 subjects among the population of subjects aged 65 years and over : $360(24 \%)$ subjects agreed to participate (192 women and 168 men). The letter sent to each subject indicated that it was necessary to be able to come on her or his own to the Centre. All the subjects were mobile, did not require help for walking or day-to-day living, and their degree of physical and mental activity was judged appropriate for age. A brief history was performed on each subject to exclude those with any disease, diet therapy or drug known to affect nutritional status. As all the subjects who came to the Centre fulfilled the conditions mentioned, all of them were considered as apparently healthy. Samples were divided into four-age groups for both sexes : 65-69 years, 70-74 years, 75-79 years and 80 years and over. The overall study group included 626 subjects (65-97 years), 337 women (65-97 years) and 289 men (65-89 years). Two-stage cluster sampling was used. First, a sample of two primary sampling units was chosen (two areas in France). From each chosen primary sampling unit, one sample (the elderly subjects) was selected. The total sample size of 626 subjects was determined in order to yield approximately a desired precision for variables at the $5 \%$ confidence interval using relative information about the order of magnitude in standard deviation of measured quantitative variables. Proportional allocation is frequently used for the determination of the total sample size to the individual strata because it is simple and often quite effective. The study was in accordance with the ethical standards of the Committee on Human Experimentation of the C.H.U. de Tours.

The weight of each subject was measured without shoes and after voiding. The clothes below the waist were not taken off but the pockets were emptied. The weight of the clothes was not deducted. The precision of the scale used was $\pm 0.5 \mathrm{~kg}$. Height was measured with bare feet close together, back and heels against the upright bar of the height scale, standing erect and looking straight ahead. The equipment used for the height measurement consisted of a vertical bar with a height scale, and an attached horizontal bar which slid down to the subject's crown. The precision of the height scale was $0.005 \mathrm{~m}$.

Body mass index (Quételet index) was calculated as weight $(\mathrm{kg})$ divided by height ${ }^{2}\left(\mathrm{~m}^{2}\right)$. The anthropometric variables were measured according to the method defined by Tanner $\&$ Whitehouse (1962). The mid-point between the tip of the acromion and the olecranon process was marked while the subject held the forearm in horizontal position. The midupper arm circumference $(\mathrm{AC})$ was measured on each subject's arm hanging freely along the trunk with a flexible inextensible tape calibrated in $\mathrm{mm}$. The measurements of skinfold thickness were made by grasping the skin and adjacent subcutaneous tissue between the thumb and forefinger with a Harpenden skinfold caliper (British Indicators Ltd, St Albans, Herts) which exerts a constant pressure of $10 \mathrm{~g} / \mathrm{mm}^{2}$ of surface area at all openings. Skinfold thickness was measured to the nearest $0.2 \mathrm{~mm}$. All measurements were taken on the right side of the body, on the four sites used in the predictive equations of Durnin \& Womersley (1974): (a) biceps, over the mid point of the muscle, midway between the tip of the acromion and the olecranon with the arm hanging along the trunk; (b) triceps, over the mid-point of the muscle midway between the tip of the acromion and the olecranon, with the upper arm hanging along the trunk; (c) subscapular, just below the tip of the inferior angle of the scapula, at an angle of about $45^{\circ}$ to the vertical; (d) suprailiac, just above the iliac crest in the mid-axillary line. The sum of these four skinfold measurements was calculated. All the anthropometric measurements were carried out by the same trained 
observer (F.L.). Each skinfold was measured three times and the mean of the three measurements was considered as the true value.

Body fat percentage of the population under 70 years was calculated from the Siri (1961) equation: $\%$ fat $=(4.95 /$ body density -4.5$) \times 100$ where body density was obtained by using the predictive equation of Durnin \& Womersley (1974), established between the body density and the $\log$ of the sum of skinfold thicknesses measured at four sites. This method has not been validated for subjects aged more than 72 years. However, Chumlea et al. (1984) showed in an elderly population that each of the four skinfolds used by Durnin \& Womersley (1974) was positively correlated with fat body weight measured by hydrodensitometry. The estimated muscle arm circumference (MAC) was derived from AC $(\mathrm{mm})$ and triceps skinfold thickness (TSF $; \mathrm{mm}$ ) by using the following equation: MAC $=$ $\mathrm{AC}-\pi$ (TSF). Corrected arm muscle area (cAMA; $\left.\mathrm{mm}^{2}\right)$ was derived from the equations of Heymsfield et al. (1982): cAMA $=\left[(\mathrm{AC}-\pi \mathrm{TSF})^{2} / 4 \pi-6.5\right]$ for the women and $\left[(\mathrm{AC}-\pi \mathrm{TSF})^{2} / 4 \pi-10\right]$ for the men. This method has not been validated for subjects aged more than 71 years.

We recorded the differences between each anthropometric variable according to age for both sexes in the Loches and Haguenau populations. When no differences were observed between Loches and Haguenau populations the subjects were pooled and the percentiles were established in each of the four age-groups according to sex.

\section{Data analysis}

In order to explore the differences among subgroups of the study population, analyses were repeated separately for males and females. Age, sex and geographic location (by dummy variables) were treated as explanatory variables in separate least squares regression analyses of each of the measurements. A likelihood ratio $F$ test was used to assess the significance of the interaction terms as a group and a simultaneous $t$ test procedure was used to eliminate subsets of the first-order interactions to simplify the model. This procedure permits the screening of effects in large models without increasing the overall size of the test. The 10th and 90th percentiles defined lower and upper reference intervals (Solberg, 1981). The variations in anthropometric indices according to age were treated for both sexes and for both areas by regression analysis.

\section{RESULTS}

Anthropometric data of the two geographic areas according to the four age-groups are presented in Table 1. We observed that in the age group 65-69 years the weights of men and women in Loches were lower than those in Haguenau. In men of this age-group anthropometric indices related to percent body fat and to muscular mass were lower in Loches than those in Haguenau, whereas in women only anthropometric indices related to percent body mass were lower in Loches than those in Haguenau. In men aged 70-74 years weight and anthropometric indices related to muscular mass were lower in Loches than in Haguenau. It can be observed that the geographical differences were limited to the 65-69 years age-group for the women and to the 65-69 and 70-74 years age-groups for the men. Regression analysis according to age for the anthropometric indices of both sexes and both areas are reported in Table 2. We observed that height, weight, TSF, four skinfolds thickness, AC and MAC were negatively correlated with age in the Loches and Haguenau women. In contrast, height and TSF did not change in the men from Loches and Haguenau, although the other anthropometric indices were negatively correlated with age 
Table 1. Anthropometric indices for an elderly French population according to age-groups $\dagger$

\begin{tabular}{|c|c|c|c|c|c|c|c|c|}
\hline & \multicolumn{4}{|c|}{ Men ( $n$ 289) } & \multicolumn{4}{|c|}{ Women ( $n$ 337) } \\
\hline & \multicolumn{2}{|c|}{ Haguenau } & \multicolumn{2}{|c|}{ Loches } & \multicolumn{2}{|c|}{ Haguenau } & \multicolumn{2}{|c|}{ Loches } \\
\hline & Mean & $\mathrm{SD}$ & Mean & SD & Mean & SD & Mean & SD \\
\hline \multicolumn{9}{|l|}{$65-69$ years } \\
\hline$n$ & \multicolumn{2}{|c|}{70} & \multicolumn{2}{|c|}{32} & \multicolumn{2}{|c|}{72} & \multicolumn{2}{|c|}{49} \\
\hline Age (years) & $66 \cdot 5$ & $1 \cdot 3$ & $67 \cdot 4^{*}$ & $1 \cdot 5$ & $66 \cdot 8$ & $1 \cdot 5$ & 66.9 & $1 \cdot 4$ \\
\hline $\mathrm{Wt}(\mathrm{kg})$ & $79 \cdot 6$ & $10 \cdot 4$ & $72 \cdot 9^{*}$ & $10 \cdot 4$ & $67 \cdot 1$ & $12 \cdot 2$ & $62 \cdot 0^{*}$ & $11 \cdot 1$ \\
\hline Height (m) & $1 \cdot 69$ & $0 \cdot 07$ & 1.67 & $0 \cdot 05$ & $1 \cdot 58$ & $0 \cdot 06$ & $1 \cdot 58$ & 0.0 \\
\hline Body mass index $\left(\mathrm{kg} / \mathrm{m}^{2}\right)$ & 27.9 & $3 \cdot 4$ & $26 \cdot 3$ & $2 \cdot 6$ & $26 \cdot 9$ & $5 \cdot 1$ & $24 \cdot 9 *$ & $4 \cdot 2$ \\
\hline Arm circumference $(\mathrm{cm})$ & $30 \cdot 6$ & $3 \cdot 4$ & $29 \cdot 0$ & $2 \cdot 9$ & $30 \cdot 6$ & $3 \cdot 4$ & $29 \cdot 0^{*}$ & $2 \cdot 9$ \\
\hline Triceps skinfold (mm) & $11 \cdot 6$ & $3 \cdot 5$ & $10 \cdot 9$ & $3 \cdot 5$ & $22 \cdot 4$ & $7 \cdot 4$ & $19 \cdot 1 *$ & $5 \cdot 2$ \\
\hline Four skinfolds (mm) & $57 \cdot 7$ & $16 \cdot 0$ & $50 \cdot 4^{*}$ & $14 \cdot 8$ & $75 \cdot 5$ & $26 \cdot 2$ & $63 \cdot 8^{*}$ & $18 \cdot 3$ \\
\hline Muscle arm circumference $(\mathrm{cm})$ & $27 \cdot 6$ & $2 \cdot 1$ & $26 \cdot 7^{*}$ & $1 \cdot 7$ & $23 \cdot 6$ & $2 \cdot 1$ & $23 \cdot 0$ & $2 \cdot 0$ \\
\hline Corrected arm muscle area $\left(\mathrm{cm}^{2}\right)$ & $51 \cdot 0$ & $8 \cdot 8$ & $47 \cdot 1^{*}$ & $7 \cdot 1$ & $38 \cdot 2$ & $7 \cdot 9$ & $36 \cdot 0$ & $7 \cdot 7$ \\
\hline Percentage fat & $21 \cdot 1$ & $3 \cdot 4$ & $19 \cdot 4^{*}$ & 3.9 & $33 \cdot 0$ & $5 \cdot 4$ & $30 \cdot 9 *$ & $4 \cdot 0$ \\
\hline \multicolumn{9}{|l|}{$70-74$ years } \\
\hline$n$ & \multicolumn{2}{|c|}{32} & \multicolumn{2}{|c|}{31} & \multicolumn{2}{|c|}{50} & \multicolumn{2}{|c|}{29} \\
\hline Age (years) & $71 \cdot 8$ & $1 \cdot 4$ & $71 \cdot 7$ & $1 \cdot 4$ & $71 \cdot 4$ & $1 \cdot 4$ & $71 \cdot 3$ & $1 \cdot 4$ \\
\hline Wt $(\mathrm{kg})$ & $80 \cdot 4$ & $13 \cdot 5$ & $71 \cdot 7^{*}$ & $10 \cdot 0$ & $66 \cdot 6$ & $12 \cdot 8$ & $62 \cdot 7$ & $10 \cdot 9$ \\
\hline Height $(\mathrm{m})$ & 1.68 & $0 \cdot 06$ & 1.67 & 0.07 & 1.57 & 0.05 & $1 \cdot 55$ & 0.05 \\
\hline Body mass index $\left(\mathrm{kg} / \mathrm{m}^{2}\right)$ & $28 \cdot 4$ & $4 \cdot 1$ & $26 \cdot 0$ & $4 \cdot 4$ & $26 \cdot 9$ & $4 \cdot 5$ & $26 \cdot 0$ & $4 \cdot 4$ \\
\hline Arm circumference $(\mathrm{cm})$ & $31 \cdot 4$ & $3 \cdot 3$ & $29 \cdot 4^{*}$ & $2 \cdot 7$ & $30 \cdot 2$ & $3 \cdot 5$ & $28 \cdot 9$ & 3.0 \\
\hline Triceps skinfold (mm) & $12 \cdot 1$ & $6 \cdot 3$ & $10 \cdot 7$ & $6 \cdot 7$ & $21 \cdot 0$ & $7 \cdot 3$ & $19 \cdot 4$ & $5 \cdot 7$ \\
\hline Four skinfolds $(\mathrm{mm})$ & 56.9 & $21 \cdot 0$ & $46 \cdot 1^{*}$ & $17 \cdot 0$ & $70 \cdot 8$ & $26 \cdot 2$ & $64 \cdot 8$ & 21.9 \\
\hline Muscle arm circumference $(\mathrm{cm})$ & $27 \cdot 6$ & $2 \cdot 4$ & $26 \cdot 1^{*}$ & $2 \cdot 9$ & $23 \cdot 6$ & $2 \cdot 0$ & $22 \cdot 8$ & 1.9 \\
\hline \multicolumn{9}{|l|}{$75-79$ years } \\
\hline$n$ & \multicolumn{2}{|c|}{34} & \multicolumn{2}{|c|}{28} & \multicolumn{2}{|c|}{34} & \multicolumn{2}{|c|}{38} \\
\hline Age (years) & $77 \cdot 1$ & 1.4 & 76.9 & $1 \cdot 5$ & $77 \cdot 1$ & $1 \cdot 5$ & $77 \cdot 0$ & $1 \cdot 2$ \\
\hline $\mathrm{Wt}(\mathrm{kg})$ & 73.7 & $12 \cdot 6$ & $73 \cdot 9$ & 60 & $61 \cdot 2$ & $10 \cdot 6$ & $62 \cdot 1$ & $10 \cdot 4$ \\
\hline Height $(m)$ & 1.67 & 0.07 & 1.69 & $0 \cdot 06$ & $1 \cdot 54$ & 0.06 & $1 \cdot 54$ & 0.06 \\
\hline Body mass index $\left(\mathrm{kg} / \mathrm{m}^{2}\right)$ & $26 \cdot 4$ & $4 \cdot 0$ & $25 \cdot 9$ & $2 \cdot 3$ & $26 \cdot 9$ & $4 \cdot 5$ & $26 \cdot 0$ & $4 \cdot 4$ \\
\hline Arm circumference $(\mathrm{cm})$ & $29 \cdot 3$ & $2 \cdot 6$ & $29 \cdot 4$ & 1.9 & $28 \cdot 7$ & $3 \cdot 3$ & $29 \cdot 1$ & $3 \cdot 3$ \\
\hline Triceps skinfold (mm) & $12 \cdot 0$ & $5 \cdot 1$ & $10 \cdot 0$ & $2 \cdot 9$ & $19 \cdot 5$ & $5 \cdot 5$ & $19 \cdot 1$ & 6.6 \\
\hline Four skinfolds (mm) & $49 \cdot 1$ & $17 \cdot 9$ & $44 \cdot 0$ & $10 \cdot 9$ & $65 \cdot 8$ & $18 \cdot 9$ & $64 \cdot 8$ & $21 \cdot 6$ \\
\hline Muscle arm circumference $(\mathrm{cm})$ & $25 \cdot 5$ & $0 \cdot 3$ & $26 \cdot 3$ & $1 \cdot 8$ & $22 \cdot 7$ & $2 \cdot 2$ & $23 \cdot 1$ & $2 \cdot 1$ \\
\hline \multicolumn{9}{|l|}{$\geqslant 80$ years } \\
\hline$n$ & & & & & & & & \\
\hline Age (years) & $82 \cdot 7$ & $2 \cdot 7$ & $82 \cdot 9$ & $2 \cdot 8$ & $82 \cdot 2$ & $2 \cdot 0$ & $83 \cdot 4$ & $4 \cdot 8$ \\
\hline Wt $(\mathrm{kg})$ & $70 \cdot 0$ & $7 \cdot 8$ & 67.8 & $9 \cdot 2$ & $59 \cdot 2$ & $12 \cdot 2$ & $56 \cdot 4$ & $11 \cdot 8$ \\
\hline Height $(\mathrm{m})$ & $1 \cdot 68$ & 0.06 & $1 \cdot 66$ & $0-06$ & $1 \cdot 54$ & $0 \cdot 05$ & 1.53 & 0.06 \\
\hline Body mass index $\left(\mathrm{kg} / \mathrm{m}^{2}\right)$ & 24.9 & $2 \cdot 5$ & $24 \cdot 6$ & $3 \cdot 0$ & $26 \cdot 9$ & $4 \cdot 5$ & $26 \cdot 0$ & $4 \cdot 4$ \\
\hline Arm circumference $(\mathrm{cm})$ & $28 \cdot 1$ & $2 \cdot 2$ & $27 \cdot 9$ & $2 \cdot 7$ & $28 \cdot 3$ & $3 \cdot 7$ & $27 \cdot 3$ & $3 \cdot 2$ \\
\hline Triceps skinfold (mm) & $10 \cdot 2$ & $3 \cdot 4$ & $9 \cdot 2$ & $2 \cdot 9$ & $18 \cdot 1$ & $6 \cdot 8$ & $16 \cdot 0$ & $5 \cdot 2$ \\
\hline Four skinfolds (mm) & $42 \cdot 9$ & $11 \cdot 3$ & $41 \cdot 0$ & $13 \cdot 0$ & $58 \cdot 2$ & $20 \cdot 8$ & $52 \cdot 5$ & $17 \cdot 7$ \\
\hline Muscle arm circumference $(\mathrm{cm})$ & $24 \cdot 9$ & $2 \cdot 0$ & $25 \cdot 0$ & $2 \cdot 3$ & $22 \cdot 5$ & $2 \cdot 5$ & $22 \cdot 3$ & $2 \cdot 1$ \\
\hline
\end{tabular}

Mean values were significantly different from those for Haguenau: ${ }^{*} P<0.05$.

$\dagger$ For details of procedures, see pp. 295-297. 
Table 2. Regression analysis of anthropometric indices according to age for an elderly French population $\ddagger$

\begin{tabular}{|c|c|c|c|c|}
\hline \multirow[b]{2}{*}{$n \ldots$} & \multicolumn{2}{|c|}{ Men } & \multicolumn{2}{|c|}{ Women } \\
\hline & $\begin{array}{l}\text { Haguenau } \\
168\end{array}$ & $\begin{array}{c}\text { Loches } \\
121\end{array}$ & $\begin{array}{l}\text { Haguenau } \\
192\end{array}$ & $\begin{array}{l}\text { Loches } \\
145\end{array}$ \\
\hline Height (m) & $-0 \cdot 11$ & -0.02 & $-0.32 \dagger \dagger$ & $-0 \cdot 28 * * *$ \\
\hline Wt $(\mathrm{kg})$ & $-0 \cdot 34 \dagger \dagger$ & $-0 \cdot 18^{*}$ & $-0.23+t$ & $-0 \cdot 19^{*}$ \\
\hline Arm circumference $(\mathrm{cm})$ & $-0.48+\dagger$ & $-0 \cdot 34 * * *$ & $-0.25+1$ & $-0.19^{*}$ \\
\hline Triceps skinfold (mm) & $-0 \cdot 09$ & $0 \cdot 13$ & $-0.22+\dagger$ & $-0 \cdot 19^{*}$ \\
\hline Four skinfolds (mm) & $-0.32+\dagger$ & $-0 \cdot 25^{* *}$ & $-0.24+\dagger$ & $-0 \cdot 19^{*}$ \\
\hline Muscle arm circumference $(\mathrm{cm})$ & $-0.53 \dagger \dagger$ & $-0 \cdot 28 * *$ & $-0 \cdot 18^{* *}$ & $-0 \cdot 18^{*}$ \\
\hline
\end{tabular}

as in women. Anthropometric percentiles for women and men are reported in Tables 3 and 4 for variables and age-groups for which there were no significant differences between regions.

\section{DISCUSSION}

Our study reports the sex-related anthropometric data of healthy non-institutionalized subjects living in two different areas of France and expressed as age-groups. It is the first study in France of anthropometric data in these age-groups, particularly in individuals aged more than 80 years. Obviously with regard to the sampling method used and to the small size of the sample studied these data cannot be strictly considered as reference, but rather as typical values in the elderly, so any generalization with other areas must be made with caution. We observed an interregional difference in women in the 65-69 years agegroup which was not evident in the other three age-groups. In men interregional differences were observed in the 65-69 and 70-74 years age-groups but not in the other two groups. In women aged 65-69 years, weight was lower in the Loches group and among anthropometric indices those related to body fat percentage were lower but not those related to muscle mass. Thus, the differences in weight may be explained by a lower percentage of body fat. Whether environmental factors such as energy intake and level of physical activity account for these differences cannot be assessed from the present study. In men aged 65-74 years, weight, fat percentage (65-69 years age-group), and indices related to muscle mass were lower in the Loches group than those in the Haguenau group. In the 65-69 years age-group, differences must be interpreted with caution because of a higher mean age in the Loches men. In the 70-74 years age-group the lower body weight observed in the Loches men might be explained by both a lower percentage of fat and less muscle mass. However, the determination of geographical location for anthropometric data in the elderly raises some dilemma of interpretation. So, we cannot dismiss the possibility that the variations observed are related to the recruitment of small groups of people on a regional basis.

In the regression analysis concerning the variations in the anthropometric indices according to age, we observed the same variations in the Haguenau and Loches male populations as in the Haguenau and Loches female populations. The negative correlation between age and the anthropometric variables related to body fat suggests a progressive 
Table 3. Anthropometric percentiles for elderly French women*

\begin{tabular}{|c|c|c|c|c|c|c|c|c|}
\hline & \multirow{2}{*}{$\begin{array}{c}\text { Age-groups } \dagger \\
\text { (years) }\end{array}$} & \multirow[b]{2}{*}{ Mean } & \multirow[b]{2}{*}{ SD } & \multicolumn{5}{|c|}{ Percentiles } \\
\hline & & & & 10 th & 25 th & 50 th & 75 th & 90 th \\
\hline Height (m) & $\begin{aligned} & 65-69 \\
& 70-74 \\
& 75-79 \\
&> 80\end{aligned}$ & $\begin{array}{l}1.58 \\
1.56 \\
1.54 \\
1.53\end{array}$ & $\begin{array}{l}0.05 \\
0.05 \\
0.06 \\
0.06\end{array}$ & $\begin{array}{l}1.51 \\
1.50 \\
1.46 \\
1.46\end{array}$ & $\begin{array}{l}1.55 \\
1.52 \\
1.51 \\
1.5\end{array}$ & $\begin{array}{l}1.58 \\
1.56 \\
1.54 \\
1.53\end{array}$ & $\begin{array}{l}1.61 \\
1.60 \\
1.58 \\
1.57\end{array}$ & $\begin{array}{l}1.64 \\
1.63 \\
1.62 \\
1.60\end{array}$ \\
\hline Wt $(\mathrm{kg})$ & $\begin{aligned} & 70-74 \\
& 75-79 \\
> & 80\end{aligned}$ & $\begin{array}{l}64 \cdot 9 \\
61 \cdot 9 \\
58 \cdot 0\end{array}$ & $\begin{array}{l}12 \cdot 2 \\
10 \cdot 4 \\
12 \cdot 0\end{array}$ & $\begin{array}{c}50 \cdot 4 \\
50 \\
44\end{array}$ & $\begin{array}{c}56 \cdot 3 \\
54 \cdot 6 \\
49\end{array}$ & $\begin{array}{l}64 \\
61 \\
56\end{array}$ & $\begin{array}{l}70 \\
68 \cdot 4 \\
65\end{array}$ & $\begin{array}{l}80-6 \\
76 \\
75\end{array}$ \\
\hline Body mass index $\left(\mathrm{kg} / \mathrm{m}^{2}\right)$ & $\begin{aligned} & 70-74 \\
& 75-79 \\
&> 80\end{aligned}$ & $\begin{array}{l}26 \cdot 5 \\
25 \cdot 9 \\
24 \cdot 6\end{array}$ & $\begin{array}{l}4 \cdot 4 \\
3 \cdot 8 \\
4 \cdot 4\end{array}$ & $\begin{array}{l}21.7 \\
21.9 \\
19.7\end{array}$ & $\begin{array}{l}23 \cdot 2 \\
23 \cdot 8 \\
22 \cdot 0\end{array}$ & $\begin{array}{l}25 \cdot 7 \\
25 \cdot 7 \\
23 \cdot 5\end{array}$ & $\begin{array}{l}29 \cdot 2 \\
28 \cdot 4 \\
27 \cdot 0\end{array}$ & $\begin{array}{l}32 \cdot 8 \\
30 \cdot 7 \\
29 \cdot 7\end{array}$ \\
\hline Arm circumference $(\mathrm{cm})$ & $\begin{aligned} & 70-74 \\
& 75-79 \\
&> 80\end{aligned}$ & $\begin{array}{l}29 \cdot 7 \\
29 \cdot 0 \\
27 \cdot 8\end{array}$ & $\begin{array}{l}3 \cdot 3 \\
3 \cdot 2 \\
3 \cdot 6\end{array}$ & $\begin{array}{l}26 \cdot 0 \\
25 \cdot 3 \\
23 \cdot 1\end{array}$ & $\begin{array}{l}27 \cdot 5 \\
27 \cdot 4 \\
25 \cdot 5\end{array}$ & $\begin{array}{l}29 \cdot 1 \\
28 \cdot 9 \\
27 \cdot 4\end{array}$ & $\begin{array}{c}31 \cdot 6 \\
30 \cdot 9 \\
30\end{array}$ & $\begin{array}{l}34 \cdot 4 \\
32 \cdot 5 \\
32 \cdot 6\end{array}$ \\
\hline Triceps skinfold (mm) & $\begin{aligned} & 70-74 \\
& 75-79 \\
&> 80\end{aligned}$ & $\begin{array}{l}20 \cdot 2 \\
19 \cdot 4 \\
17 \cdot 1\end{array}$ & $\begin{array}{l}6 \cdot 8 \\
6 \cdot 0 \\
6 \cdot 2\end{array}$ & $\begin{array}{c}12 \cdot 1 \\
12 \\
10 \cdot 2\end{array}$ & $\begin{array}{l}15 \cdot 5 \\
15 \cdot 8 \\
12 \cdot 7\end{array}$ & $\begin{array}{l}19 \cdot 7 \\
19 \cdot 1 \\
15 \cdot 9\end{array}$ & $\begin{array}{l}24 \cdot 1 \\
22 \cdot 3 \\
20 \cdot 3\end{array}$ & $\begin{array}{c}29 \cdot 2 \\
27 \cdot 3 \\
26\end{array}$ \\
\hline Four skinfolds (mm) & $\begin{aligned} & 70-74 \\
& 75-79 \\
&> 80\end{aligned}$ & $\begin{array}{l}68 \cdot 1 \\
65 \cdot 8 \\
55 \cdot 4\end{array}$ & $\begin{array}{l}23 \cdot 6 \\
19 \cdot 9 \\
19 \cdot 7\end{array}$ & $\begin{array}{c}39 \cdot 3 \\
42 \cdot 9 \\
31\end{array}$ & $\begin{array}{l}52 \cdot 5 \\
54 \cdot 8 \\
39 \cdot 5\end{array}$ & $\begin{array}{l}66 \cdot 3 \\
64 \cdot 9 \\
53 \cdot 6\end{array}$ & $\begin{array}{l}82 \cdot 7 \\
77 \cdot 2 \\
68 \cdot 0\end{array}$ & $\begin{array}{r}101 \cdot 6 \\
92.0 \\
81 \cdot 6\end{array}$ \\
\hline Muscle arm circumference $(\mathrm{cm})$ & $\begin{aligned} 65-69 \\
70-74 \\
75-79 \\
>80\end{aligned}$ & $\begin{array}{l}23 \cdot 4 \\
23 \cdot 3 \\
22 \cdot 9 \\
22 \cdot 4\end{array}$ & $\begin{array}{l}2 \cdot 1 \\
2 \cdot 0 \\
2 \cdot 2 \\
2 \cdot 3\end{array}$ & $\begin{array}{l}20 \cdot 7 \\
20 \cdot 9 \\
20 \cdot 5 \\
19 \cdot 7\end{array}$ & $\begin{array}{l}22 \cdot 0 \\
21.9 \\
21 \cdot 7 \\
20 \cdot 5\end{array}$ & $\begin{array}{l}23 \cdot 2 \\
23 \cdot 2 \\
22 \cdot 7 \\
22 \cdot 3\end{array}$ & $\begin{array}{l}24 \cdot 8 \\
24 \cdot 4 \\
24 \cdot 2 \\
23 \cdot 4\end{array}$ & $\begin{array}{l}26 \cdot 1 \\
26 \cdot 3 \\
25 \cdot 8 \\
25 \cdot 6\end{array}$ \\
\hline Corrected arm muscle area $\left(\mathrm{cm}^{2}\right)$ & $65-69$ & $37 \cdot 3$ & 7.9 & $27 \cdot 5$ & 31.9 & $36 \cdot 4$ & $42 \cdot 5$ & 47.8 \\
\hline
\end{tabular}

* For details of subjects and procedures, see Table 1 and pp. 295-297.

$\dagger$ No. of subjects for each age-group: 65-69 years $102,70-74$ years $63,75-79$ years $62,>80$ years 62 .

loss of fat with advancing age, but it is also possible that the subcutaneous fat is not really representative of the total fat mass in the elderly (Chumlea \& Baumgartner, 1989). In the men we observed no correlations between age and TSF, while a correlation existed with the four skinfolds. These results agree with those of Burr \& Phillips (1984) who observed that the decline in TSF with advancing age was more marked in women than in men. The fact that a negative correlation existed for the sum of four skinfolds in men might suggest that it could be a better indicator than TSF of fat loss secondary to age in elderly men. The decline in $\mathrm{AC}$ and MAC values with advancing age in both sexes suggests a progressive loss of muscle bulk with age and agrees with the findings of Burr \& Phillips (1984). Whereas there was no relationship between age and height in the men, height steadily decreased in the women. These findings may be explained by the higher prevalence of osteoporosis in women than in men (Raisz, 1988).

In the absence of French anthropometric reference values for the population over 65 years the American reference values are used as an alternative. However, there are substantial differences between countries (Frisancho, 1981; Burr \& Phillips, 1984; Constans et al. 1990). In the United States various anthropometric indices have been published for the healthy population, including large adult surveys, but not for people over 75 years (Frisancho, 1981). When we compared our results with the 50th American percentile values in the 70-74 years population, TSF and MAC were higher in the 
Table 4. Anthropometric percentiles for elderly French men*

\begin{tabular}{|c|c|c|c|c|c|c|c|c|}
\hline & \multirow{2}{*}{$\begin{array}{c}\text { Age-groups } \uparrow \\
\text { (years) }\end{array}$} & \multirow[b]{2}{*}{ Mean } & \multirow[b]{2}{*}{ SD } & \multicolumn{5}{|c|}{ Percentiles } \\
\hline & & & & 10 th & 25 th & 50 th & 75 th & 90 th \\
\hline Height $(\mathrm{m})$ & $\begin{aligned} & 65-69 \\
& 70-74 \\
& 75-79 \\
\geqslant & 80\end{aligned}$ & $\begin{array}{l}1.68 \\
1.67 \\
1.68 \\
1.67\end{array}$ & $\begin{array}{l}0.07 \\
0.08 \\
0.07 \\
0.08\end{array}$ & $\begin{array}{l}1.60 \\
1.59 \\
1.59 \\
1.59\end{array}$ & $\begin{array}{l}1.63 \\
1.64 \\
1.64 \\
1.62\end{array}$ & $\begin{array}{l}1.68 \\
1.68 \\
1.68 \\
1.67\end{array}$ & $\begin{array}{l}1.74 \\
1.72 \\
1.71 \\
1.70\end{array}$ & $\begin{array}{l}1.78 \\
1.74 \\
1.78 \\
1.75\end{array}$ \\
\hline $\mathrm{Wt}(\mathrm{kg})$ & $\begin{aligned} & 75-79 \\
> & 80\end{aligned}$ & $\begin{array}{l}73.8 \\
69 \cdot 9\end{array}$ & $\begin{array}{r}12 \cdot 6 \\
7.8\end{array}$ & $\begin{array}{l}61 \\
58 \cdot 1\end{array}$ & $\begin{array}{l}64 \cdot 5 \\
65 \cdot 5\end{array}$ & $\begin{array}{l}71 \cdot 5 \\
69 \cdot 5\end{array}$ & $\begin{array}{c}84 \\
74 \cdot 5\end{array}$ & $\begin{array}{c}93 \\
79 \cdot 3\end{array}$ \\
\hline Body mass index $\left(\mathrm{kg} / \mathrm{m}^{2}\right)$ & $\begin{aligned} & 70-74 \\
& 75-79 \\
&> 80\end{aligned}$ & $\begin{array}{l}27 \cdot 2 \\
26 \cdot 2 \\
24 \cdot 8\end{array}$ & $\begin{array}{l}4 \cdot 1 \\
3 \cdot 3 \\
2 \cdot 8\end{array}$ & $\begin{array}{l}21 \cdot 8 \\
21 \cdot 2 \\
21 \cdot 8\end{array}$ & $\begin{array}{l}24 \cdot 3 \\
24 \cdot 4 \\
23 \cdot 2\end{array}$ & $\begin{array}{l}27 \cdot 4 \\
25 \cdot 7 \\
24 \cdot 5\end{array}$ & $\begin{array}{l}29 \cdot 3 \\
28 \cdot 9 \\
26 \cdot 3\end{array}$ & $\begin{array}{l}30 \cdot 8 \\
31 \cdot 8 \\
28 \cdot 4\end{array}$ \\
\hline Arm circumference $(\mathrm{cm})$ & $\begin{aligned} & 75-79 \\
> & 80\end{aligned}$ & $\begin{array}{l}29 \cdot 3 \\
28 \cdot 0\end{array}$ & $\begin{array}{l}0 \cdot 3 \\
2 \cdot 4\end{array}$ & $\begin{array}{l}26.9 \\
24.9\end{array}$ & $\begin{array}{c}28 \\
26 \cdot 6\end{array}$ & $\begin{array}{l}29 \cdot 0 \\
28 \cdot 3\end{array}$ & $\begin{array}{l}30 \cdot 7 \\
29 \cdot 6\end{array}$ & $\begin{array}{l}32 \cdot 7 \\
31\end{array}$ \\
\hline Triceps skinfold $(\mathrm{mm})$ & $\begin{aligned} 65-69 \\
70-74 \\
75-79 \\
>80\end{aligned}$ & $\begin{array}{r}11 \cdot 4 \\
11 \cdot 4 \\
11 \cdot 1 \\
9 \cdot 7\end{array}$ & $\begin{array}{l}3 \cdot 5 \\
6 \cdot 5 \\
4 \cdot 3 \\
3 \cdot 2\end{array}$ & $\begin{array}{l}7 \cdot 7 \\
7 \cdot 0 \\
6 \cdot 9 \\
6.1\end{array}$ & $\begin{array}{c}9 \cdot 1 \\
8 \cdot 0 \\
8 \\
7 \cdot 9\end{array}$ & $\begin{array}{l}10 \cdot 8 \\
10 \\
10 \\
9 \cdot 2\end{array}$ & $\begin{array}{l}13 \\
11.6 \\
13 \\
11.4\end{array}$ & $\begin{array}{l}16 \cdot 8 \\
17 \cdot 5 \\
17 \cdot 4 \\
13 \cdot 9\end{array}$ \\
\hline Four skinfolds (mm) & $\begin{aligned} & 75-79 \\
> & 80\end{aligned}$ & $\begin{array}{l}46 \cdot 8 \\
42 \cdot 0\end{array}$ & $\begin{array}{l}15 \cdot 2 \\
12 \cdot 1\end{array}$ & $\begin{array}{l}30 \cdot 6 \\
26 \cdot 1\end{array}$ & $\begin{array}{l}36 \cdot 7 \\
32 \cdot 4\end{array}$ & $\begin{array}{l}43 \cdot 4 \\
43 \cdot 1\end{array}$ & $\begin{array}{c}56 \cdot 7 \\
50\end{array}$ & $\begin{array}{l}67 \cdot 2 \\
56 \cdot 4\end{array}$ \\
\hline Muscle arm circumference $(\mathrm{cm})$ & $\begin{aligned} & 75-79 \\
> & 80\end{aligned}$ & $\begin{array}{l}25 \cdot 9 \\
24 \cdot 9\end{array}$ & $\begin{array}{l}1 \cdot 8 \\
1 \cdot 3\end{array}$ & $\begin{array}{l}23 \cdot 7 \\
22 \cdot 0\end{array}$ & $\begin{array}{l}24 \cdot 5 \\
23 \cdot 4\end{array}$ & $\begin{array}{l}25 \cdot 8 \\
25 \cdot 3\end{array}$ & $\begin{array}{l}26 \cdot 9 \\
26 \cdot 8\end{array}$ & $\begin{array}{l}28 \cdot 1 \\
27 \cdot 6\end{array}$ \\
\hline
\end{tabular}

* For details of subjects and procedures, see Table 1 and pp. 295-297.

$\uparrow$ No. of subjects for each age-group: $65-69$ years $102,70-74$ years $63,75-79$ years $62,>80$ years 62 .

American women and TSF higher in the men. No comparison can be made for people over 75 years because no American percentiles have been published for subjects over 75 years.

Other authors have published anthropometric measurements in small samples of healthy elderly populations but they did not report the percentile values (Vir \& Love, 1980; McEvoy \& James, 1982; Kemm \& Allcock, 1984; Side et al. 1991). Burr \& Phillips (1984) reported representative samples of elderly people in South Wales, including 1500 subjects aged 65 years and more, divided into five age-groups. They observed that the indices of $\mathrm{BMI}, \mathrm{AC}$ and TSF are quite similar to the results obtained from various parts of the UK but lower than the American values. They assumed that these differences could not be explained only by the inclusion of institutionalized people in their sample because there were too few of them. When our 50 th percentile values are compared with those of Burr \& Phillips (1984) for the corresponding age-groups, we observe lower AC, MAC and TSF in the Welsh population than in our population. In contrast, BMI is higher in Welsh women and similar in men. These results emphasize the importance of establishing local values for the elderly population.

The authors gratefully acknowledge Dr J. L. Schlienger and Mrs Ch. Morra for their invaluable help in the organization of the recruitment of the subjects in Haguenau and in Loches.

\section{REFERENCES}

Burr, M. L. \& Phillips, K. M. (1984). Anthropometric norms in the elderly. British Journal of Nutrition 51, $165-169$. 
Chumlea, W. C. \& Baumgartner, R. N. (1989). Status of anthropometry and body composition data in elderly subjects. American Journal of Clinical Nurition 50, 1158-1166.

Chumlea, W. C., Roche, A. F. \& Webb, P. (1984). Body size, subcutaneous fatness and total body fat in older adults. International Journal of Obesity 8, 313-317.

Constans, T., Bacq, Y., Bertrand, P., Beaugerie, A., Babault, C., Delarue, J. \& Lamisse, F. (1990). The American Anthropometric Norms are not suitable to assess the nutritional status of a French population. Clinical Nutrition 9, 168-171.

Durnin, J. V. G. A. \& Womersley, J. (1974). Body fat assessed from total body density and its estimation from skinfold thickness. Measurements on 481 men and women aged from 16 to 72 years. British Journal of Nutrition 32, 77-97.

Frisancho, A. R. (1981). New norms of upper limb fat and muscle areas for assessment of nutritional status. American Journal of Clinical Nutrition 34, 2540-2545.

Heymsfield, S. B., MacManus, C., Smith, J., Stevens, V. \& Nixon, D. W. (1982). Anthropometric measurement of muscle mass: revised equations for calculating bone free arm muscle area. American Journal of Clinical Nutrition 36, 680-690.

Kemm, J. R. \& Allcock, J. (1984). The distribution of supposed indicators of nutritional status in elderly patients. Age and Ageing 13, 21-28.

Lehmann, A. B. (1989). Undernutrition in elderly people. Age and Ageing 18, 339-353.

McEvoy, A. W. \& James, O. F. W. (1982). Anthropometric indices in normal elderly subjects. Age and Ageing 11 , 97100.

Raisz, L. G. (1988). Local and systemic factors in the pathogenesis of osteoporosis. Nen' England Joumal of Medicine 318, 818-828.

Side, X., Mingtang, S., Shuquan, Z., Zhaomei, M., Yinzhi, X., Yuhun, L., Jun, W. \& Kui, J. (1991). Anthropometric and dietary survey of elderly Chinese. British Journal of Nutrition 66, 355-362.

Siri, W. E. (1961). Body composition from fluid spaces and density, analysis of methods. In Techniques for Measuring Body Composition, pp. 223-244 [J. Brozek and A. Henschel, editors], Washington, DC: National Academy Press.

Solberg, H. E. (1981). Statistical treatment of collected reference values and determination of reference limits. In Reference Values in Laboratory Medicine, pp. 193-201. [R. Grasbek and T. Alstrom, editors]. New York: John Wiley \& Sons.

Tanner, J. M. \& Whitehouse, R. H. (1962). Standard for subcutaneous fat in British children. British Medical Journal 1, 446-450.

Vir, S. C. \& Love, A. H. G. (1980). Anthropometric measurements in the elderly. Gerontology 26, 1-8. 